\title{
STUDYING HISTORY IN AN ISLAMIC CONTEXT AND ITS EFFECTS ON STUDENT AWARENESS: A CASE STUDY OF MUSLIM STUDENTS AT SAUDI UNIVERSITIES
}

\author{
Hasnah Alghamdi $^{*} \&$ Meguellati Achour ${ }^{* *}$
}

\begin{abstract}
This study measures the effects of studying history on the cultural awareness of students. The determinants of studying history included under this research are the importance of history and Islamic history. The researchers sampled 315 students as respondents determined using the snowball technique who answered the online survey developed through Google forms with an appended consent form. The survey link was sent to the student respondents via social media. These students are studying at Jeddah University, King Abdelaziz University, and King Saud University. Their ages ranged from 17 to more than 39 years. The results of this study reveal a strong, positive and significant correlation between studying history and student awareness, student awareness and the importance of history as well as student awareness and Islamic history.
\end{abstract}

Keywords: History, Awareness, Muslim Students, Universities, Islamic history

\section{Introduction}

It is important to be aware of one's past and current surroundings. This is particularly important for students living in volatile and rapidly changing regions, such as the Middle East, to make sense of the developments and situate them within appropriate contexts. Awareness of current events requires reading and understanding of history because most current events result from past events. In this way, history plays an integral part regarding not only how people understand their society, but also themselves and the people around them. This is because history plays a crucial role in our lives. ${ }^{1} \mathrm{Be}$ referring to history, people orientate themselves and create meaning in both their personal lives and the world around them. ${ }^{2}$ The primary purpose of studying history is to broaden the students' horizons.

While framing the syllabus, proper care should be taken to develop the students' awareness and understanding of society from their immediate environment to the country and the world. ${ }^{3}$ Some university students fail to acknowledge the importance of history. ${ }^{4}$ The Saudi history syllabus is considered very important because it focuses on teaching students about Islamic history which represents an essential part of their religion. This history syllabus is full of historical facts, dates, names and events which students must memorise. ${ }^{5}$

The teaching of history enables the students to achieve various instructional objectives hierarchically. These objectives are knowledge, understanding, critical thinking, practical skills, interests and attitudes relating to historical matters. This will involve looking at various periods of history and will, of course, involve looking at various other countries and cultures. The attitudes that the study of history can develop are particularly important, and students should show respect toward other people, ways of life, ideas, etc.; know about other religions and faiths; establish friendship with other people; understand the main religions and their principles; cooperate with others in social and historical activities; appreciate cultural differences; and believe in equality for man irrespective of caste, class,

\footnotetext{
* Hasnah Alghamdi, Lecturer, Department of History and Heritage, Faculty of Social Sciences, Jeddah University, Saudi Arabia. Email: hassnaghamdi@hotmail.com.

${ }_{* *}$ Meguellati Achour (Corresponding Author), Senior Lecturer, Department of Management, Faculty of Economics, Commercial and Management, University of Mohamed El Bachir El Ibrahimi, Bordj Bou Arréridj, Algeria. Email: megue2009@gmail.com.

${ }^{1}$ Klas-Göran Karlsson (1999), Historia som vapen: Historiebruk och Sovjetunionens upplösning 1985-1995, Stockholm: Natur och kultur, pp. 50-53.

${ }_{2}^{2}$ Robert Thorp (2016), "Uses of History in History Education, Umeå University \& Dalarna University, Print \& media," Umeå universitet. http://umu.diva-portal.org/.

3 Pallavi Talekau, Jyotrimayee Nayak and S. Harichandan (2007), "History," Course Hero, retrieved 13 $3^{\text {th }}$ March 2020, https://www.coursehero.com/file/27772503/HISTORYpdf.

${ }^{4}$ Ministry of Education and Culture (2012), Pemikiran tentang pembinaan kesadar-an sejarah.

${ }^{5}$ Mobarak Saeed N. Hamdan Al-Shahrani (1995), History teaching methods and students' attainments and attitudes in the first year of secondary schooling in Saudi Arabia, Doctoral thesis, Durham University, available at Durham E-Theses Online: http://etheses.dur.ac.uk/1126/.
} 
creed, colour and religion. ${ }^{6}$ Most studies that have addressed the effect of the study of history on individual' awareness were conducted from the Western perspective. Since there are limited empirical studies that address the importance of studying and understanding the history and its role on individual awareness and Muslim students at the university level, the present study seeks to assess the role of studying history and its effects of cultural awareness of Muslim students at Saudi universities. For this purpose, this study will attempt to highlight the effect of studying history on cultural awareness of Muslim students at Saudi universities.

\section{Cultural/Social Awareness of Students}

Cultural awareness is defined as the ability to recognise and understand the effects of culture on people's values and behaviours. ${ }^{7}$ Cultural awareness can also be defined as the process of examining one's cultural experiences and professional background and its contributions to bias toward other cultures. $^{8}$ Cultural awareness is knowing different beliefs, traditions, roles and lifestyles. It is comprised of self-awareness of one's culture, awareness of other's culture, and awareness of the discrepancy between cultures and cultural influence on individuals' values, beliefs and behaviours. The essence of cultural awareness is alertness to distinctions between home and host cultures. It facilitates the generation of culturally appropriate behaviours in cross-cultural communication and interactions. ${ }^{9}$ Cultural awareness of places, events and people is often linked to reading and studying history and understanding the past.

Studying history makes a person more aware of culture. It enables him/her to understand better and accept the actions of different people, such as understanding the racial tensions that occurred in AlAqsa Mosque in 1948 that continue to exist presently. People are linked in one way or another to history, and delving deeper into the study of civilisations reveals its importance to forming one's character and personality, especially religions civilisations. ${ }^{10}$ The importance of studying history lies in the fact that history is one of the most important elements upon which any society depends in its development or its decline, and that history has a close relationship with various sciences. The study of these sciences enriches one's understanding, directs academic pursuit and cultivates a sense of respect for their history.

The cross-cultural comparison can also help the students identify and understand the cultural elements involved in what they are reading. Due to their different history and different tradition, people of different culture follow different customs. Every country has its long-established beliefs and religion, which enormously influences its people's mode of thinking and concept of value. ${ }^{11}$ Mass media, such as TV and radio broadcasting, movies, newspapers, and the popular internet etc., are also considered an insightful means of obtaining cultural knowledge, for they reflect people's lifestyles in terms of variety, contemporaneousness and truth. ${ }^{12}$

\section{The Importance of Studying History}

History helps us to understand human society and its evolution. It records the activities and thoughts of man while also inspiring the new generation by describing past glories. In this way, history is a record of human beings and their activities. ${ }^{13}$ History is an incremental process that illustrates the social, political, cultural, economic, religious, scientific, etc., contributions of people and civilisations.

\footnotetext{
${ }^{6}$ Ali Naser Almogbel (2015), “International Education Issues in Saudi Arabia's Public Education Curricula: An Analytical Study,” Journal of International Education and Leadership, Vol. 5, No. 1, pp. 1-24.

${ }^{7}$ William D. Wunderle (2006), Through the Lens of Cultural Awareness: A primer for US Armed Forces Deploying to Arab and Middle Eastern Countries, Kansas: Military Bookshop.

${ }^{8}$ Campinha-Bacote, J. (2007), The process of cultural competence in the delivery of healthcare services: The journey continues, Cincinnati, Ohio: Transcultural C.A.R.E. Associates.

${ }^{9}$ Xiaowen Chen (2017), A Validation Study of the Cross Cultural Competence Navigator, Master thesis, Guangdong University of Foreign Studies, Melbourne, Florida.

10 Mohammed Merwan (2018), “The importance of history in our life," retrieved 13 June 2020, https://mawdoo3.com/\%D8\%A3\%D9\%87\%D9\%85\%D9\%8A\%D8\%A9_\%D8\%A7\%D9\%84\%D8\%AA\%D8\%A7\%D8\%B1\%D9\%8A\%D8 \%AE_\%D9\%81\%D9\%8A_\%D8\%AD $\%$ D9\%8A\%D8\%A7\%D8\%AA\%D9\%86\%D8\%A7.

${ }^{11}$ Guoqiao Wang (2018), “On the Strategies of Enhancing Students' Cultural Awareness in College English Teaching," English Language Teaching," Vol. 11, No. 12, pp. 116-120.

${ }^{12}$ Guoqiao Wang (2018), “On the Strategies of Enhancing Students' Cultural Awareness,” pp. 116-120.

${ }^{13}$ Ghosh, S (2019), “An Introduction of History," International Journal of Advance Research and Innovative Ideas in Education, Vol. 5, No. 4, pp. 716-716.
} 
Various events such as war, revolutionary changes, and the rise and fall of empires are common events of history. It includes the history of literature, history of politics, history of science, history of religion, ${ }^{14}$ as well as the history of social and cultural events, to name a few.

History is the study of life in past societies that could be used to direct present and future developments. It is the story of people in time, and an inquiry into the past based on evidence. It is an inquiry into what happened in the past, when it happened, and how it happened. ${ }^{15}$ History is, therefore, only a subset of the past. As a discipline, history is a study of the past, but it will only reveal a portion of the past and should be done so as objectively as possible. ${ }^{16}$ Historians share common conceptions about why we should study history. ${ }^{17 ; 18}$ Studying history is essential because it allows us to understand our past, which in turn allows us to understand our present. If we want to know how and why our world is the way it is today, we have to look to history for answers.

People often say that "history repeats itself," but if we study the successes and failures of the past, we may, ideally, be able to learn from our mistakes and avoid repeating them in the future. History aims at helping students to understand present social, political, religious and economic conditions. Without knowledge of history, we cannot have the background of our religion, customs, institutions, administrations and so on. The teaching of history helps students to explain the present, to analyse it and understand present-day problems at the national and international level accurately and objectively. ${ }^{19}$

Studying history can provide us with a clear picture of what is happening currently in the world, especially in the Muslim world and the Middle East. The study of history is important because it allows one to make more sense of the current world. One can look at past economic, cultural and political trends and be able to offer reasonable predictions of what will happen next in today's world. History is inescapable as a subject of serious study. The past causes the present and the future. History can help us develop a better understanding of the world, understand societal norms, cultural differences, and personal experiences, and understand who we are. We need to develop a sense of self as well as learn to understand others and give us the tools we need to be citizens who are proud of our existence. $^{20}$

Muslim historians generally state that the science of history is the knowledge of the conditions, customs, genealogies of the people, and their personalities as well. The goal of history is to know the past conditions of people and benefit from them, just as history has been linked to the hadiths of the Prophet (PBUH). In our modern era, researchers see that history deals with everything related to human efforts, whether they are peaceful or non-peaceful, or efforts related to arts, economics, education, and religion. ${ }^{21}$ Sometimes modern history is sufficient to explain a significant development, but we often need to take another look to determine the causes of change. Only by studying history can we understand how things change. It is only through history that we can begin to understand the factors that cause change, and only through history can we understand what elements of an institution or society continue on despite change. ${ }^{22}$

The following points illustrate the importance of studying history:

- The study of history helps to know people and their contemporaries, and it is important in identifying names without error in the event that those names are similar.

- It is history that bears witness to the past and the present, and what the future can be. ${ }^{23}$

\footnotetext{
${ }^{14}$ Ghosh, S, (2019), “An Introduction of History,” pp. 716-716

15 Talekau, Nayak and Harichandan (2007), "History."

16 Underwood, Jr. R. M (2008), “Defining History,” retrieved 20 ${ }^{\text {th }}$ April 2020, https://pdftotextconverter.online/converted/003d64eb/defining-history-robert-milton-underwood-jr/szmgbzqybw75qliqazcfvbn9lwr0cs119ritkmzrpdf.pdf.

${ }^{17}$ McNeill, W. H (1985), "Why study history? American Historical Association,” retrieved $21{ }^{\text {st }}$ April 2020, http://www.historians.org/aboutaha-and-membership/aha-history-andarchives/archives/why-study-history.

${ }^{18}$ P. N. Stearns (1998), "Why study history? American Historical Association."

${ }^{19}$ Talekau, Nayak and Harichandan (2007), "History."

${ }^{20}$ D. Gruber and P. W. P. Poets (2012), Poetry with Passion Global Poets, Lulu.com.

${ }^{21}$ Abdul Rahman Al-Sheikh (n.d.), Introduction to the History of History, Riyadh: Dar Al-Merikh, pp. 19.

${ }^{22}$ P. N. Stearns (2013), "Why study history? American Historical Association."

${ }^{23}$ Abdel-Alim Khidr (n.d.), Muslims and History Writing: A Study in the Islamic Foundations of History Science, United States of America: International Institute of Islamic Thought, pp. 62-64.
} 
- The importance of studying history lies in taking lessons and learning from the past, avoiding committing the same mistakes, and trying to find solutions to these errors. ${ }^{24}$

- Through the study of history, we can know the truth of events and facts and their authenticity.

- When studying history, we can be inspired by the good role models that history offers, which have had a great impact on life and are unforgettable role models over time.

- Nations have rushed to study history for its importance in knowing and realising the truth and taking positions from experiences to plan and link it with the present. Had it not been for the importance of history, we would not have found regular scientific research that gives great attention to historical studies until they are based on accurate and solid foundations. ${ }^{25}$

- The study of history provides the student with skills other than enriching knowledge about the past, such as making him acquire analytical skills. This skill is very valuable and important in many jobs, in addition to gaining the ability to prioritise information to make appropriate decisions about something.

The Islamic golden age is traditionally dated from the mid- $7^{\text {th }}$ century to the mid- $13^{\text {th }}$ century when Muslims established the largest empires in history. During this period, artists, engineers, scholars, physicians, poets, philosophers, geographers and traders in the Islamic empires contributed to the world immensely in agriculture, economics, sciences, technology, sociology, philosophy, industry, law and literature. They preserved earlier traditions and added inventions, discoveries and innovations of their own. At that time, the Muslim world became a major intellectual centre for sciences, philosophy, medicine, sociology, psychology, culture, and education. ${ }^{26}$ So, we can say that studying history can be a source of awareness for us in different aspects such as economic, culture, values, religions, changes and development in societies and so on. For this purpose, this study highlights the importance of studying history and identify whether it impacts one's understanding of contemporary issues.

\section{Validity of Research}

Validity explains how well the collected data covers the actual area of investigation. ${ }^{27}$ Validity "measures what is intended to be measured". ${ }^{28}$ There are three basic approaches to the validity of tests and measures as shown by Mason and Bramble, ${ }^{29}$ namely content validity, construct validity and criterion-related validity. In this study, the researchers focus on content validity, which is defined as "the degree to which items in an instrument reflect the content universe to which the instrument will be generalised". ${ }^{30}$ The instruments of this study were questionnaires for university students developed by the researchers. In order to determine the validity of these questionnaires, each question was reviewed based on feedback from three experts. The researchers developed aspects of studying history. The data were collected and pretested among 40 participants (students) studying at Saudi universities and analysed using the Statistical Package for Social Sciences (SPSS).

\section{Methods}

\section{Participants and Procedure}

Three hundred and fifteen (315) students as respondents were determined using the snowball technique who answered the online survey developed through Google forms with an appended consent form. The survey link was sent to the student respondents via social media. These students have been selected from different faculties at Saudi Arabia universities to participate in this study. The researchers selected this sample of students as they have sufficient knowledge of history and modern issues. The sample represented different fields of study. Their ages ranged from 21 to 50 years, and they participated voluntarily in this study. All respondents completed the online questionnaire given the difficulty to collect data directly because of COVID-19. The questionnaire

\footnotetext{
${ }^{24}$ Abdel-Alim Khidr (n.d.), Muslims and History Writing, pp. 62-64.

${ }^{25}$ Abdel-Alim Khidr (n.d.), Muslims and History Writing, pp. 62-64.

${ }^{26}$ Tahir Abdurrahman, Abubakar Abdul hakim Abdullah and kabara Auwal Halabi (2015), The Historical Contributions of Islamic Civilization in Medical and Applied Sciences: A Survey from The Muslims Product, E-Proceeding of the 2nd International Conference on Arabic Studies and Islamic Civilization, Kuala Lumpur, Malaysia.

${ }^{27}$ P. Ghauri and K. Gronhaug (2005), Research Methods in Business Studies, Harlow: FT/Prentice Hall.

${ }^{28}$ A. P. Field (2005), Discovering Statistics Using SPSS, New York: Sage Publications Inc.

${ }^{29}$ E. J. Mason and W. J. Bramble (1989), Understanding and conducting research, New York: McGraw-Hill.

${ }^{30}$ Detmar Straub, Marie-Claude Boudreau and David Gefen (2004), "Validation guidelines for IS positivist research," Communications of the Association for Information Systems, Vol. 13, pp. 380-427.
} 
contained three sections. Participants were assured that their responses would be kept confidential and utilised for the research purpose only. They were requested to complete the questionnaire by following the instructions at the top of the questionnaire.

\section{Measures}

Studying History: Studying history consisted of 21 items, but the researchers removed one item based on the confirmatory factor analysis. This variable was developed by the researcher and also cited by others. ${ }^{31 ; 32}$ The sample items include "History is important to me." (Item-1) and "The past is important to me to understand the present and the future" (Item-9). The scale uses a 5-point Likert response format, ranging from (1) "Strongly Disagree" to (5) "Strongly Agree". Table 1 presents the results of the reliability statistics and exploratory factor analysis. Most of the factor loadings for each instrument exceeded .50 , thereby meeting the required validity.

Student Awareness: Student awareness consisted of 17 items. This variable was developed by the researcher and cited by the PISA-2018-Global-Competence-Questionnaire. ${ }^{33}$ The sample items include "I respect the values of people from different cultures." (Item-8) and "I am interested in how people from various cultures see the world." (Item-4). The scale uses a 5-point Likert response format, ranging from (1) "Strongly Disagree" to (5) "Strongly Agree."

Factor Analysis: Exploratory factor analysis (EFA) was used in this study to reduce items by deleting invalid ones. This study used principal component analysis with Varimax rotation, with a factor loading cutoff of 0.5 . In this study, the researchers used thirty-one (20) items. After using exploratory factor analysis, three (3) items have been removed. The Kaiser-Meyer-Olkin (KMO) measure should be greater than .70. The KMO test tells us whether or not each factor predicts enough items. Here, it is .949 , so that is good. The Bartlett test should be significant (i.e. a significance value of less than .05); in this study Bartlett's Test of Sphericity $=.000<.05$ means it is significant (Please see Table 1 in Appendix A). This means that the variables are correlated highly enough to provide a reasonable basis for factor analysis, as in this case.

In this study, studying history consists of the importance of history, which contains 13 items, and Islamic history, which contains four items. Table 2 presents the results of the reliability statistics and exploratory factor analysis. Most of the factor loadings for each instrument exceeded 0.50 , meeting the significance level of convergent validity. Furthermore, the research instrument was tested for reliability using Cronbach's coefficient, as reported in Table 2, with scale reliability greater than .70 considered reliable. ${ }^{34}$

Many studies have shown that extracting factors on the basis of the Eigenvalues being greater than one can lead to an overestimation of the number of retained factors. ${ }^{35}$ Accordingly, the Eigenvalues of the factors retained were greater than 1.5. This reduces the risk of over factoring, which implies that retaining factors that have little theoretical basis can lead to misinterpretation, and they may not result in the replicability of results ${ }^{36 ; 37}$. In multi-factor scales, total variance explained more than $60 \%$ is considered acceptable. Furthermore, in social sciences, a solution that accounts for more than $60 \%$ of the variance is considered acceptable. ${ }^{38}$ The factor loadings found as a result of Varimax vertical rotation are presented in Table 2. Factor 1 represents the maximum variance, i.e. $60.242 \%$, and factor $2(8.555 \%)$. However, retaining a one-factor solution can lead to under-factoring, as it may cause

\footnotetext{
${ }^{31}$ Christopher W. Berg (2019), "Why study history? An examination of undergraduate students' notions and perceptions about history," Historical Encounters: A journal of historical consciousness, historical cultures, and history education, Vol. 6, No. 1, pp. 54-71.

${ }^{32}$ Patrick Devine-Wright (1999), Tracing the Hand of History: The Role of Social Memories in the Northern Ireland Conflict, Doctoral thesis, University of Surrey.

${ }^{33}$ Programme for international student assessment (2018), “(PISA-2018-Global-Competence-Questionnaire), Questions related to global competence in the student, Questionnaire," retrieved 25 ${ }^{\text {th }}$ May 2020, http://www.historians.org/about-aha-and-membership/aha-historyandarchives/archives/why-study-history-(1998).

${ }^{34}$ Joseph F. Hair Jr., William C. Black, Barry J. Babin, Rolph E. Anderson and Ronald L. Tatham (1998), Multivariate data analysis, NJ: Prentice Hall.

${ }^{35}$ Robin K. Henson and J. Kyle Roberts (2006), "Use of exploratory factor analysis in published research," Educational and Psychological Measurement, Vol. 66, No. 3, pp. 393-416.

${ }^{36}$ Leandre R. Fabrigar, Duane T. Wegener, Robert C. MacCallum Erin J. Strahan (1999), "Evaluating the use of exploratory factor analysis in psychological research," Psychological Methods, Vol. 4, pp. 272-299.

${ }^{37}$ Henson and Roberts (2006), "Use of exploratory factor analysis in published research," pp. 393-416.

${ }^{38}$ Zikmund, Babin, Carr and Griffin (2010), Business Research Methods, USA: Cencage Learning.
} 
considerable error. ${ }^{39}$ Furthermore, the percentage variance explained by factors was acceptable (68.797\%). Table 2 in Appendix B shows that only two factors have been retained: the first factor the importance of history $(F 1)$, the second factor Islamic history $(F 2)$.

The researchers observed a noticeable improvement in the fit of the items to the one-factor model, and MI values (Modification Indices) was found as following: $\mathrm{CMIN}=321.157$; $\mathrm{DF}=108$; $\mathrm{P}$-value $=$ $.000 ; \mathrm{CFI}=.953 ; \mathrm{GFI}=.891 ; \mathrm{TLI}=.940 ; \mathrm{RMSEA}=.079 ; \mathrm{CMIN} / \mathrm{DF}=2.974, \mathrm{RMR}=.059(\mathrm{See}$ Figure 1 and Figure 2).

MODEL FIT (Before Improving):

$C M I N=563.520 ; P=.000 ; D F=118 ; C M I N / D F=4.776 ; R M R=.071 ; G F I=.821 ; T L I=.886 ;$ CFI $=.901 ;$ RMSEA $=.110$

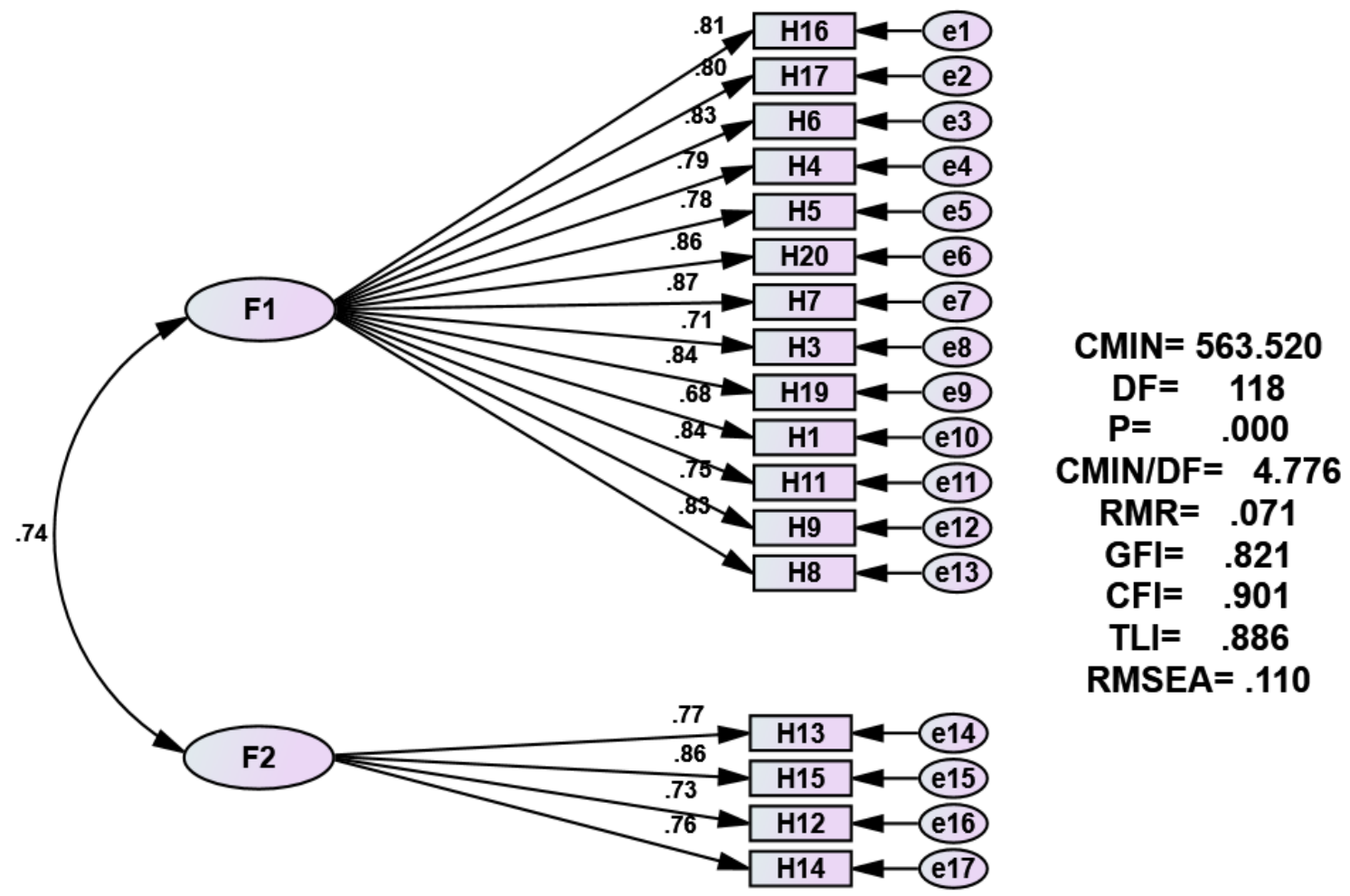

Figure 1: Confirmatory Factor Analysis Diagram of Studying History Scales (17 Items)

MODEL FIT (Improved Model):

$\mathrm{CMIN}=321.157 ; \mathrm{P}=.000 ; \mathrm{DF}=108 ; \mathrm{CMIN} / \mathrm{DF}=2.974 ; \mathrm{RMR}=.059 ; \mathrm{GFI}=.891 ; \mathrm{TLI}=.940 ;$ CFI $=.953 ;$ RMSEA $=.079$

\footnotetext{
39 James M. Wood, Douglas J. Tataryn and Richard L. Gorsuch (1996), "Effects of under- and overextraction on principal axis factor analysis with varimax rotation," Psychological Methods, Vol. 1, pp. 354-365.
} 


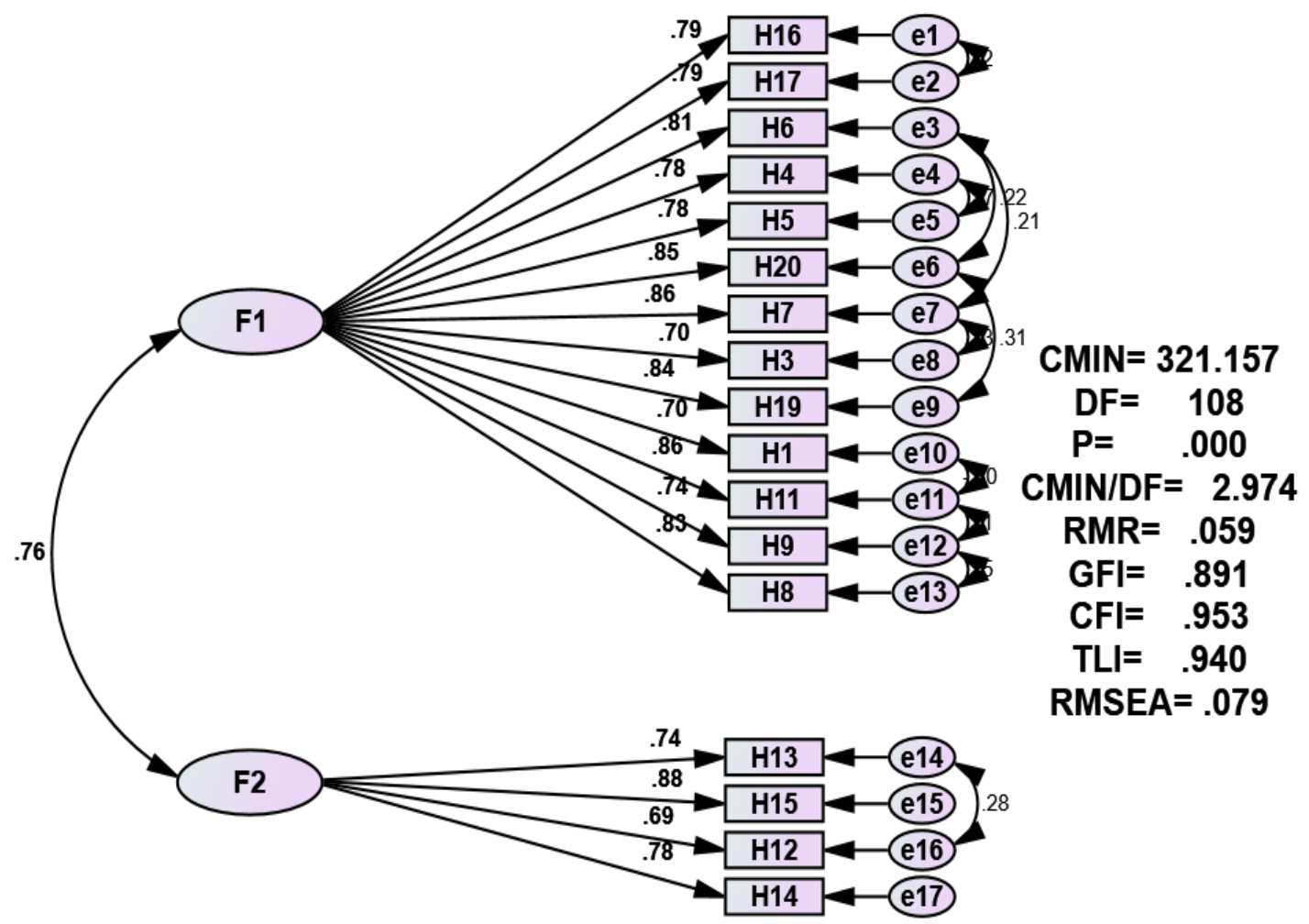

Figure 2: Confirmatory Factor Analysis for improved diagram of Studying History Scales (17 Items)

Table 1: Correlations between Studying History, the Importance of History, Islamic History, and Student Awareness

\begin{tabular}{lcccccc}
\hline Scales/Variable & $\mathbf{M}$ & S.D & $\mathbf{1}$ & $\mathbf{2}$ & $\mathbf{3}$ & $\mathbf{4}$ \\
\hline 1. Studying history & 79.9 & 18.33 & & & & \\
& 8 & & & & & \\
2. Importance of history & 65. & 15.37 & $.985^{* *}$ & 1 & & \\
& 86 & & & & & \\
3. Islamic history & 14. & 4.12 & $.773^{* *}$ & $.654^{* *}$ & 1 & \\
& 12 & & & & & \\
4. Students' Awareness & 66. & 15.14 & $.741^{* *}$ & $.732^{* *}$ & $.566^{* *}$ & 1 \\
& 63 & & & & & \\
\hline
\end{tabular}

Table 3 shows that there is a strong, positive and significant correlation respectively between studying history and student awareness $(\mathrm{r}=.741, \mathrm{p}=.000<0.01)$, student awareness and the importance of history $(\mathrm{r}=.732, \mathrm{p}=.000<0.01)$, as well as student awareness and Islamic history $(\mathrm{r}=.566, \mathrm{p}=.000<$ $0.01)$.

Table 2: Regression Analysis for Students' Awareness

\begin{tabular}{lcc}
\hline Independent Variable & B (t-value) & Sig \\
\hline Studying History & $19.175(7.682)$ & .000 \\
The Importance of History & $.778(12.619)$ & .000 \\
Islamic History & $.407(2.191)$ & .029 \\
R & .737 & \\
R Square & .544 & \\
Adjusted R Square & .539 & \\
\hline
\end{tabular}

The linear regression procedure examines the relationship between studying history as independent variable and political awareness as dependent variable using regression analysis, and the results are as shown in Table 4. Regression analysis for students' awareness: Studying history (B (t-value) $=19.175$ 
(7.682), $\mathrm{p}=.000<0.01)$; the importance of history $(\mathrm{B}$ (t-value) $=.778(12.619), \mathrm{p}=.000<0.01)$; and Islamic History $(\mathrm{B}$ (t-value) $=.407(2.191), \mathrm{p}=.000<0.05) ; \mathrm{R}=.737, \mathrm{R}$ Square $=.544$, Adjusted $\mathrm{R}$ Square $=.539$. As expected, the result of studying history is positively correlated with cultural awareness of Muslim students and significant.

\section{Discussion}

This study examined the relationship between studying history and the social/cultural awareness of university students studying at selected Saudi universities. Studying history was positively related to the social/cultural awareness of students. Studying history is important since, if any nation neglects its history, it will be in a state of confusion when planning its development; i.e. the continuity gained from studying the past is beneficial to guide the development of a broader past and present perspective. $^{40}$

\section{The Importance of Studying History}

The results of this study support previous studies. Al-Shahrani said that history is important since it studies the past events through which the present can be understood, and future trends anticipated. As we have seen, teaching history should be based not only on telling historical events but also on developing the historical thinking abilities of students. ${ }^{41}$ Empirical research on how students establish connections between the past and the present show that students on the lower levels do not motivate opinions on present situations or connect them with history. At higher levels, they can connect a current event with history as well as connect various events in the past to explanations of present situations. ${ }^{42 ; 43 ; 44}$

Studying history has played a central role in the discipline of students to develop their understanding and thought about the human condition. ${ }^{45}$ History studies can also give students ample opportunity to appreciate the interrelationship of cause and effect and to judge the relative importance of different causes. ${ }^{46}$ In addition, the study of history fulfils several purposes. Garvey and Krug ${ }^{47}$ explained that the study of history furnishes students with opportunities to know historical facts, to understand and appreciate past events, to develop the ability to evaluate and criticise these events and to practise the techniques of historical research. People might see the past to find the solution for current problems. ${ }^{48}$ By learning history, people will be creative in encountering contemporary challenges.

\section{Studying History and Students Awareness}

The results of this study support the relationship between studying history and students' awareness. There is a positive and significant relationship between studying history and students' awareness which states that when studying history increase, there is an expected increase in students' awareness. People who are studying history will have the ability to compare the difference among periods, cultures and social systems. ${ }^{49}$ This ability is the manifestation of an individual's historical awareness. ${ }^{50}$ Nations that do not understand their history are like individuals who have lost their memories (suffering from amnesia or dementia) so that they should search to find their identity through the darkness. ${ }^{51}$ In other words, a nation that does not have historical awareness is a nation that has lost its identity. Therefore, historical awareness should exist in every citizen for the development

\footnotetext{
${ }^{40}$ Goeffery Partington (1980), The Idea of an Historical Education, Windsor: Nfer Publishing Company.

${ }^{41}$ Al-Shahrani (1995), History teaching methods and students' attainments.

${ }^{42}$ Catherine Duquette (2015), "Relating historical consciousness to historical thinking through assessment" in Kadriye Ercikan and Peter Seixas (eds.), New Directions in Assessing Historical Thinking, New York: Routledge, pp. 51-63.

${ }^{43}$ David Rosenlund (2016), History education as content, methods or orientation? A study of curriculum prescriptions, teacher made tasks and student strategies, Doctoral thesis, Malmö University.

${ }^{44}$ Johan Sandahl (2015), "Civic consciousness: A viable concept for advancing students' ability to orient themselves to possible futures?," Historical Encounters, Vol. 2, No. 1, pp. 1-15.

${ }^{45}$ Low-Beer, A., and Blyth, J. (1991), Teaching History to Younger Children, London: The Historical Association.

${ }^{46}$ de Marco, N., and Medley, R. (1989), Profiling in History, A guide for teachers. London: Historical Association.

${ }^{47}$ Brian Garvey and Mary Krug (1977), Models of History Teaching in the Secondary School, Oxford: Oxford University Press.

${ }^{48}$ Louis R. Gottschalk (1956), Understanding history: A premier of historical method, New York: Alfred A. Knopf.

${ }^{49}$ Bahri Ata (2009), "The Turkish prospective history teachers' understanding of analogy in history education," International Journal of Historical Learning, Teaching and Research, Vol. 8, No. 1, 6-18.

${ }^{50}$ Aisiah, Suhartono and Sumarno (2016), "The Measurement Model of Historical Awareness," Research and Evaluation in Education, Vol.

2, No. 2, pp. 108-121.

${ }^{51}$ Kartodirdjo (1993), Pembangunan bangsa, Yogyakarta: Aditya Media.
} 
of the nation. ${ }^{52}$ For this purpose, the students need to be supported to study and understand history to optimise their attempts to make connections between past, present and future, ${ }^{53}$ as students are considered the future leaders of any country.

History provides opportunities to learn from past experiences. History is the record of human experiences that could contain advantages from the multiple domains of science and experience. ${ }^{54}$ The past experiences relevant to the present experiences in history will be the basis for formulating actions for the future. ${ }^{55}$ Historical knowledge is useful for interpreting the future. ${ }^{56}$ The study of the past should help us to live better in the present and prepare for the future ${ }^{57}$ History's purpose for students is to help them better understand the world they live in and prepare for the future. ${ }^{58}$ Al-Qablawi ${ }^{59}$ believes that history contributes to building spiritual and humanitarian work among students and strengthens human relations. Sulaiman ${ }^{60}$ pointed out that the benefits of the study of history include the development of moral values, sense of responsibility among students, appreciation for others and the development of learners' thinking about historical events.

\section{Islamic History and Students Awareness}

The results of this study support the relationship between studying Islamic history and awareness of Muslim students. There is a positive and significant relationship between studying Islamic history and awareness of Muslim students. It means that when studying Islamic history, there is an expected increase in awareness of Muslim students about different issues around their life in certain aspects. Al-Khraisha ${ }^{61}$ viewed that history contributes to an individual's personality through acquiring human experiences that have accumulated since the start of life to awaken the person and to restore confidence to the importance and ability to work and tender. In the Islamic world, the study of Islamic history helps a lot in understanding many of the events that occur in the Middle East, especially since many conflicts exist in the Arab region, such as the events of Jerusalem, the Levant, Iraq and North Africa. If Muslims want to succeed, they must first understand their religion by understanding the achievements of their predecessors who contributed significantly to the human civilisation. This is achieved through the study of history and Islamic heritage. ${ }^{62}$

\section{Conclusion}

This research focused on studying history and the awareness of students in Saudi Arabian universities. Studying history was found to have a significant and positive effect on the awareness of students. People who are studying history will have the ability to understand many current issues. Studying history has played a central role in the discipline of students to develop their understanding and thought about the human condition. History studies can also give students ample opportunity to appreciate the interrelationship of cause and effect and to judge the relative importance of different causes.

It has been observed that history in the Islamic world, including Saudi Arabia, depends on memorising facts, leading to the ease of forgetting this knowledge and rendering it a dull subject. For future research, the researchers should do more research to help people and students in particular and provide them with knowledge and highlights the benefits of studying history. The department of curriculums at universities and teachers should understand the needs and wants of students especially in the issues that related to citizen, culture, values, religions, changes and development in societies, as well as social issues in general. University policy should enhance students study history either as an

\footnotetext{
${ }^{52}$ Aisiah, Suhartono and Sumarno (2016), "The Measurement Model of Historical Awareness," pp. 108-121.

${ }^{53}$ Dick Van Straaten, Arie Wilschut and Ron Oostdam (2015), "Making history relevant to students by connecting past, present and future: a framework for research," Journal of Curriculum Studies, Vol. 48, No. 4, pp. 1-24.

${ }^{54}$ Gottschalk (1956), Understanding history: A premier of historical method.

${ }_{55}^{5}$ John Tosh (1984), The pursuit of history: Aim, method, and new directions in the study of modern history, New York, NY: Longman.

${ }^{56}$ Sjamsuddin, H. (2012), Metodologi sejarah, Yogyakarta: Ombak.

${ }^{57}$ Berg (2019), "Why study history?," pp. 54-71.

${ }^{58}$ Peter Seixas and Tom Morton (2013), The big six historical thinking concepts, Toronto, Canada: Nelson.

${ }^{59}$ Al-Qablawi, S. (2004), Efficiencies of Teaching Social Studies, Amman: Al-Shrooq House.

${ }^{60}$ Sulaiman, J. (1999), History Teaching Methods, Damascus: Damascus University Publications.

${ }^{61}$ Al-Khraisha, A. (1997), "Social Studies Teachers' Knowledge Level at the Secondary Stage in Jordan to the Nature of History and the Effect of Sex, Qualification and Specialization," Jarash Journal for Research and Studies, Vol. 3, No. 1, pp. $135-170$.

62 Mabara, A. M., and Mates. (2019). The importance of studying Islamic history, access on $21^{\text {st }}$ May 2020, https://alqabas.com/en/article/5732011-the-importance-of-studying-islamic history.
} 
elective or compulsory subject and reward them based on merit and achievement. This can help students to increase their level of awareness about different issues. History should be studied because it is essential to individuals and society, and because it helps students understand the current events around them.

\section{References}

Abdel-Alim K. (n.d.), Muslims and History Writing: A Study in the Islamic Foundations of History Science, United States of America: International Institute of Islamic Thought.

Aisiah, S. and Sumarno (2016), "The Measurement Model of Historical Awareness," Research and Evaluation in Education, Vol. 2, No. 2, 108-121.

Al-Khraisha, A. (1997), "Social Studies Teachers' Knowledge Level at the Secondary Stage in Jordan to the Nature of History and the Effect of Sex, Qualification and Specialisation," Jarash Journal for Research and Studies, Vol. 3, No. 1, 135-170.

Al-Shahrani, M. S. N. H. (1995), History teaching methods and students' attainments and attitudes in the first year of secondary schooling in Saudi Arabia, Doctoral thesis, Durham University. Available at Durham E-Theses Online: http://etheses.dur.ac.uk/1126/.

Almogbel, A. N. (2015), "International Education Issues in Saudi Arabia's Public Education Curricula: An Analytical Study," Journal of International Education and Leadership, Vol. 5, No. 1, $1-24$.

Al-Qablawi, S. (2004), Efficiencies of Teaching Social Studies, Amman: Al-Shrooq House.

Ata, B. (2009), "The Turkish prospective history teachers' understanding of analogy in history education," International Journal of Historical Learning, Teaching and Research, Vol. 8, No. 1, 6-18.

Berg, C, W. (2019), "Why study history? An examination of undergraduate students' notions and perceptions about history," Historical Encounters: A journal of historical consciousness, historical cultures, and history education, Vol. 6, No. 1, 54-71.

de Marco, N. and Medley, R. (1989), Profiling in History, A guide for teachers, London: Historical Association.

Duquette, C. (2015), "Relating historical consciousness to historical thinking through assessment" in Kadriye Ercikan and Peter Seixas (eds.), New Directions in Assessing Historical Thinking, New York: Routledge, 51-63.

Fabrigar, L. R., Wegener, D. T., MacCallum, R. C. and Strahan, E. J. (1999), "Evaluating the use of exploratory factor analysis in psychological research," Psychological Methods, Vol. 4, 272-299.

Field, A. P. (2005), Discovering Statistics Using SPSS, New York: Sage Publications Inc.

Guoqiao W. (2018), “On the Strategies of Enhancing Students' Cultural Awareness in College English Teaching," English Language Teaching," Vol. 11, No. 12, 116-120.

Ghosh, S. (2019), "An Introduction of History," International Journal of Advance Research and Innovative Ideas in Education, Vol. 5, No. 4, 713-716.

Underwood, Jr. R. M. (2008), “Defining History," retrieved $20^{\text {th }}$ May 2020, https://pdftotextconverter.online/converted/003d64eb/defining-history-robert-miltonunderwoodjr/szmgbzqybw75qliqazcfvbn9lwr0cs119ritkmzrpdf.pdf.

Gruber, D. and Poets, P. W. P. (2012), Poetry with Passion Global Poets, Lulu.com. 
Ghauri, P. and Gronhaug, K. (2005), Research Methods in Business Studies, Harlow: FT/Prentice Hall.

Garvey, B., and Krug, M. (1977), Models of History Teaching in the Secondary School, Oxford: Oxford University Press.

Gottschalk, L. (1956), Understanding history: A premier of historical method, New York: Alfred A. Knopf.

Hair, J. J. F., Black, C. W., Babin, B. J., Anderson, R. E. and Tatham, R. L. (1998), Multivariate data analysis, NJ: Prentice Hall.

Hariyono (1995), Mempelajari sejarah secara efektif, Jakarta: Pustaka Jaya.

Henson, R. K. and Roberts, J. K. (2006), "Use of exploratory factor analysis in published research," Educational and Psychological Measurement, Vol. 66, No. 3, 393-416.

Karlsson, K. G. (1999), Historia som vapen: Historiebruk och Sovjetunionens, Stockholm: Natur och kultur.

Kartodirdjo (1993), Pembangunan bangsa, Yogyakarta: Aditya Media.

Low-Beer, A. and Blyth, J. (1991), Teaching History to Younger Children, London: The Historical Association.

Mabara, A. M. and Mates (2019), "The importance of studying Islamic history," access on $21^{\text {st }}$ May 2020, https://alqabas.com/en/article/5732011-the-importance-of-studying-islamic- history.

Mason, E. J. and Bramble, W. J. (1989), Understanding and conducting research, New York: McGraw-Hill.

Merwan, M. (2018), "The importance of history in our life," retrieved $13^{\text {th }}$ June 2020 , https://mawdoo3.com.

Ministry of Education and Culture (2012), Pemikiran tentang pembinaan kesadar-an sejarah.

McNeill, W. H. (1985), "Why study history? American Historical Association," retrieved $21^{\text {st }}$ April 2020, http://www.historians.org/about-aha-and-membership/aha-history-andarchives/archives/whystudy-history.

Pallavi Talekau, Jyotrimayee Nayak and S. Harichandan (2007), "History," Course Hero, retrieved $13^{\text {th }}$ March 2020, https://www.coursehero.com/file/27772503/HISTORYpdf.

Patrick, D. W. (1999), Tracing the Hand of History: The Role of Social Memories in the Northern Ireland Conflict, Doctoral thesis, University of Surrey.

Partington, G. (1980), The Idea of an Historical Education, Windsor: Nfer Publishing Company.

Programme for international student assessment (2018), “(PISA-2018-Global-CompetenceQuestionnaire), Questions related to global competence in the student, Questionnaire," retrieved $25^{\text {th }}$ May 2020, http:/www.historians.org/about-aha-and-membership/aha-historyandarchives/archives/why-study-history-(1998).

Rosenlund, D. (2016), History education as content, methods or orientation? A study of curriculum prescriptions, teacher made tasks and student strategies, Doctoral thesis, Malmö University.

Robert, T. (2016), "Uses of History in History Education, Umeå University \& Dalarna University, Print \& media," Umeå universitet. http://umu.diva-portal.org/. 
Journal of Al-Tamaddun, Vol. 15 (2), 2020, 1-13

Sandahl, J. (2015), "Civic consciousness: A viable concept for advancing students' ability to orient themselves to possible futures?," Historical Encounters, Vol. 2, No. 1, 1-15.

Seixas, P. and Morton, T. (2013), The big six historical thinking concepts, Toronto, Canada: Nelson.

Sjamsuddin, H. (2012), Metodologi sejarah, Yogyakarta: Ombak.

Sheehan, M. (2011), "Historical significance' in the senior curriculum," New Zealand Journal of Educational Studies, Vol. 46, No. 2, 35-45.

Stearns, P. N. (2013), "Why study history? American Historical Association."

Stevens, J. (2002), Applied Multivariate Statistics for the Social Sciences, Mahwah, NJ: Lawrence Erlbaum Associates.

Straaten, D. V., Wilschut, A. and Oostdam, R. (2015), "Making history relevant to students by connecting past, present and future: a framework for research," Journal of Curriculum Studies, Vol. 48, No. 4, 1-24.

Straub, D., Boudreau, M.-C. and Gefen, D. (2004), "Validation guidelines for IS positivist research," Communications of the Association for Information Systems, Vol. 13, 380-427.

Sulaiman, J. (1999). History Teaching Methods. Damascus University Publications, Damascus, Syria.

Tahir, A., Abubakar, A. A. and Kabara, A. H. (2015), The Historical Contributions of Islamic Civilization in Medical and Applied Sciences: A Survey from The Muslims Product, E-Proceeding of the 2nd International Conference on Arabic Studies and Islamic Civilization, Kuala Lumpur, Malaysia.

Tosh, J. (1984), The pursuit of history: Aim, method, and new directions in the study of modern history, New York: Longman.

Wood, J. M., Tataryn, D. J. and Gorsuch, R. L. (1996), "Effects of under- and overextraction on principal axis factor analysis with varimax rotation," Psychological Methods, Vol. 1, 354-365.

Zikmund, W. G., Babin, B. J., Carr, J. C. and Griffin, M. (2010), Business Research Methods, USA: Cencage Learning. 
Appendices

Appendix $A$

Table 1: KMO and Bartlett's Test

Kaiser-Meyer-Olkin Measure of Sampling Adequacy. $\quad \mathbf{. 9 4 9}$

Bartlett's Test of Sphericity $\quad \mathrm{df} \quad 136$

Sig. $\quad \mathbf{0 0 0}$

\section{Appendix B}

Table 2: Varimax rotated factor loadings of the studying history items $(\mathrm{N}=315)$

\begin{tabular}{|c|c|c|c|c|}
\hline No & Items & F1 & F2 & $\begin{array}{r}\text { Alpha } \\
(\alpha)\end{array}$ \\
\hline & & & & .957 \\
\hline 16 & $\begin{array}{l}\text { Respected Islamic history events make me } \\
\text { optimistic. }\end{array}$ & .850 & & \\
\hline 17 & The Islamic history is important to me. & .791 & & \\
\hline 6 & The past tells me who I am. & .843 & & \\
\hline 4 & Whenever I read history, I feel proud. & .750 & & \\
\hline 5 & History makes me confident. & .722 & & \\
\hline 8 & $\begin{array}{l}\text { The past is important to me to understand the } \\
\text { present and the future. }\end{array}$ & .760 & & \\
\hline 20 & $\begin{array}{l}\text { History teaches me about where I come from, and } \\
\text { creates connections to the past. }\end{array}$ & .778 & & \\
\hline 7 & I am more interested in the future than in the past. & .806 & & \\
\hline 3 & $\begin{array}{l}\text { Without knowing our history, we cannot } \\
\text { understand who we are. }\end{array}$ & .731 & & \\
\hline 19 & $\begin{array}{l}\text { I feel history is very interesting, I enjoy learning } \\
\text { about previous events that have happened and how } \\
\text { we conquered the problems, bringing us to who we } \\
\text { are today. }\end{array}$ & .721 & & \\
\hline 1 & History is important to me. & .621 & & \\
\hline 11 & $\begin{array}{l}\text { The Islamic history is a memory for all Muslims in } \\
\text { the world. }\end{array}$ & .682 & & \\
\hline 9 & $\begin{array}{l}\text { Knowing about the Islamic history helps me to } \\
\text { understand what is going on now. }\end{array}$ & .589 & & \\
\hline 13 & $\begin{array}{l}\text { I have read a lot about the recent events in the } \\
\text { Middle East as it is one of the outputs of the events } \\
\text { of Islamic history. }\end{array}$ & & .852 & \\
\hline 15 & $\begin{array}{l}\text { I remember Khalid bin Al-Waleed as a good leader } \\
\text { and fighter against the enemies. }\end{array}$ & & .800 & \\
\hline 12 & $\begin{array}{l}\text { The events of Islamic history are similar to what is } \\
\text { happening today. }\end{array}$ & & .776 & \\
\hline 14 & $\begin{array}{l}\text { The Islamic history has great relevance to my life } \\
\text { today. }\end{array}$ & & .724 & \\
\hline & Coefficient Alpha $(\alpha)$. & .958 & .864 & \\
\hline & Eigen values. & 10.241 & 1.454 & \\
\hline & $\%$ of variance (total $=68.797 \%)$ & $\begin{array}{l}60.242 \\
\%\end{array}$ & $8.555 \%$ & \\
\hline
\end{tabular}


Journal of Al-Tamaddun, Vol. 15 (2), 2020, 1-13 